\title{
Comparative Efficacy of some Algal Species, Azolla, Pleurotus and Olive Mill in Controlling Root Knot Nematode on Banana
}

\author{
Samaa. M. Shawky*; Azza. A. M. Abd El-All ** and Ahlam M. Al-Ghonaimy *** \\ * Nematode Research Department, Plant Pathology Research Institute, Agricultural Research Center, \\ Giza, Egypt \\ ${ }^{* *}$ Microbiol. Department, Soils, Water \& Environment Research Institute (SWERI), Agricultural Research \\ Center (ARC), Giza, Egypt \\ ***Plant Protection Department, Nematology Unite- Desert Research Center, Cairo, Egypt
}

\begin{abstract}
The study aimed to use two culture algal Spirulina platensis, Anabaena azollae, Azolla pinnata and Pleurotus columbinus besides olive mill waste in controlling root knot nematode, Meloidogyne javanica in banana was monitored under both laboratory and commercial greenhouse conditions. Laboratory experiment revealed that high juvenile mortality percentage occurred during all the exposure periods of all treatments, the best results were after $72 \mathrm{hr}$ exposure. Spirulina platensis followed by Anabaena azollae, Azolla pinnata, Pleurotus columbinus and olive watery extract significantly increased juveniles mortality up to $70 \%$ after $72 \mathrm{~h}$ at the highest concentration of $1: 10(85.2,81.4,79.9,73.5,71.7$ and $70.1 \%$, respectively).

In the productivity greenhouse experiment, the combination of culture filtrates of Spirulina platensis, Anabaena azollae, Azolla pinnata, Pleurotus columbinus and olive mill waste water achieved the highest reduction in the number of total nematodes in both soil and roots, also in numbers of galls. In addition, all combinations significantly increased the crop yield of banana plants comparing with the individual treatment and the control.

The combined treatments significantly enhanced the $\mathrm{CO}_{2}$ evolution, dehydrogenase and nitrogenase activities over the control. It could be recommended that application of biological control agents against root knot nematode in banana is preferable to reduce the chemical nematicides inputs.
\end{abstract}

Key words: Banana, Meloidogyne javanica, Spirulina platensis, Anabaena azollae, Azolla pinnata, Pleurotus columbinus, olive mill waste water.

\section{Introduction}

Banana is a favorite commodity export for markets and local consumption and represents one of the most important and economic fruits in Egypt. Banana; Grand Naine' cultivar was studied under both field and in the high tunnel conditions. 
Root-knot nematodes, Meloidogyne spp., are among the most damaging nematodes in agriculture, causing an estimated US\$ 100 billion loss/year worldwide Oka et al. (2000). Root-knot nematode is a serious malady and causes significant losses in banana yield if not treated with nematicides. After hatching from eggs, second-stage juveniles invade roots of host plants and migrate intercellularly to differentiating vascular regions. The symptoms of nematode infection are the formation of root galls which result in growth reduction, nutrients and water uptake reduction, wilting increase and mineral deficiency, resulting in weak and poor yielding plants Abad et al. (2003). Root-knot nematodes Meloidogyne incognita and Meloidogyne javanica occur on banana and plantain roots wherever this crop is grown.

Application of chemical nematicides has been found as an effective measure for controlling nematodes but they have toxic residual effect on the environment particularly on non-target organisms and human health. In addition, the use of chemical nematicides is prohibited in organic farming. Therefore, there is an urgent need to develop alternative environmental safe strategies for controlling nematodes Anastasiadis et al. (2008). During the last decades, research on nematode control was focused on proposing strategies for the inhibition of egg hatch Westcott and Kluepfel (1993), degradation of hatching factor Oostendrop and Sikora (1989) or production of metabolites Meadows et al. (1989). Recently, one of the biological control practices attempted is the study of the nematicidal potential of cyanobacterial culture filtrates that parasitize plant-parasitic nematodes Khan et al. (2005).

Blue-green algae (Cyanobacteria) are distributed world-wide and contribute to the fertility of many agricultural ecosystems, either as free-living organisms or in symbiotic association with the water-fern Azolla Fay (1983). Azolla, a dichotomously branched free floating aquatic fern, is naturally available mostly in the tropical belt of India. The dorsal lobe which remains exposed to air has a specific cavity containing its symbiotic partner, a blue green algae Anabaena azollae. Abundant growth of Azolla not only makes a useful addition of combined nitrogen to the ecosystem but can also provide a 'green manure'. Azolla pinnata was found as a very effective agent for normal growth of root and shoot with half-standard dose of mustard oil cake. Both of these agents together created resistance to plants and toxic materials might suppress the nematode activity of galling by $M$. javanica Tahmid et al. (2002).

Cyanobacteria that excrete a great number of substances have been reported to benefit plants by producing growth-promoting regulators (PGPR), vitamins, amino acids, polypeptides, antibacterial and antifungal substances that exert phytopathogen biocontrol, and polymers, especially exopolysaccharides, that improve soil structure and exoenzyme activity Zaccaro et al. ( 2001). In productivity greenhouse experiment, the combination of mixing five algal culture filtrates of $S$. 
platensis, Oscillatoria sp., A. oryzae, N. muscorum and $P$. fragile with $A$. pinnata aqueous extract filtrate and compost extract achieved the highest reduction in the number of the $2^{\text {nd }}$ stage juveniles in soil, the numbers of galls, developmental stages, females, egg masses, egg numbers/egg mass in roots of cucumber plants comparing with the individual treatment and the non treated control. In addition, all combinations significantly improved fresh weight of roots and shoots and increased the plant yield Shawky et al. (2009).

This investigation aimed to evaluate the efficacy of Spirulina platensis, Anabaena azollae, Azolla pinnata, Pleurotus columbinus and olive mill waste water on root knot nematode, Meloidogyne incognita activity in vitro under laboratory conditions to select the most promising results to be applied in controlling $M$. javanica in banana plants under productivity greenhouse conditions.

\section{Materials and Methods}

Table (1): Physic- chemical properties of the experimental soil.

\begin{tabular}{ccccccccc}
\hline Coarse sand \% & Fine sand\% & Silt\% & Clay\% & $\mathrm{CaCO}_{3} \%$ & Texture & O.M\% \\
\hline 14.7 & 26.5 & 31.5 & 27.3 & 1.15 & Sand clay loam & 0.32 \\
\hline \multicolumn{7}{c}{ Anions (meq L } \\
\hline $\mathrm{HCO}_{3}^{-1}$ & $\mathrm{Cl}^{-}$ & $\mathrm{SO}_{4}^{--}$ & $\mathrm{K}^{+}$ & $\mathrm{Na}^{+}$ & $\mathrm{Mg}^{++}$ & $\mathrm{Ca}^{++}$ & $\mathrm{pH} \mathrm{1:2.5}$ & $\mathrm{EC}\left(\mathbf{d S ~ m}^{-1}\right)$ \\
1.0 & 10.7 & 1.3 & 0.7 & 7.5 & 1.5 & 3.3 & 7.5 & 1.3 \\
\hline \multicolumn{7}{c}{ Available nutrients $\left(\mathrm{mg} \mathrm{kg}^{-1}\right.$ soil) } \\
\hline $\mathrm{Cu}$ & $\mathrm{Zn}$ & $\mathrm{Mn}$ & $\mathrm{Fe}$ & $\mathrm{K}$ & $\mathrm{P}$ & $\mathrm{N}$ \\
0.04 & 1.7 & 1.9 & 2.3 & 393.7 & 18.5 & 59.6 \\
\hline
\end{tabular}

\section{Microorganisms and Azolla pinnata source and growth conditions}

The cyanobacteria, Anabaena azolla which isolated from Azolla pinnata Abd el all (2013) was grown on BG11 medium Rippka et al.(1979). The culture was incubated in growth chamber under continuous illumination (2000 lux) and temperature of $25^{\circ} \mathrm{C} \pm 2^{\circ}$, while Spirulina platensis was grown on Zarrouk medium Zarrouk (1966) at $35^{\circ} \mathrm{C} \pm 2$. Azolla pinnata was grown on modified Yoshida medium Yoshida et al. (1976) and strain of white rot fungi Pleurotus columbinus was grown on Potato Dextrose Agar medium, PDA Martin (1950).Microorganisms and Azolla pinnata were obtained from Agricultural Microbiology Research Department, Soils, Water and Environment Res. Inst. (SWERI), Agric. Res., Center (ARC). One strain of white rot fungi (Pleurotus columbinus) was obtained from Unit of Mushroom Production, Faculty of Agriculture, Ain Shams University

\section{Preparation of algal culture filtrates, Azolla pinnata, Pleurotus columbines and olive mill waste water}

After 30 days of incubation, each algal biomass was separated from its 
culture medium by filtration. The growth parameters of algal cultures filtrates were determined Table 2. Pleurotus columbinus was mixed in an electric mixer and Azolla pinnata was harvested from the culture medium and mixed well with distilled water $(1: 2 \mathrm{w} / \mathrm{v})$ using an electric mixer, then filtered to obtain the fresh biomass aqueous extract. The growth parameters of Azolla pinnata fresh biomass and aqueous solution are presented in Table 2. The algal culture filtrates, pleurotus and Azolla fresh biomass aqueous extract (50\%), $10 \%$ concentration of olive mill waste water were kept at $4{ }^{\circ} \mathrm{C}$.

\section{Soil biological activities}

$\mathrm{CO}_{2}$ evolution was determined according to Gaur et al. (1971), Dehydrogenase activity (DHA) was estimated according to Casida et al. (1964), nitrogenase activity was measured by acetylene reduction assay as described by Dart et al. (1972).

\section{Determination of culture growth parameters}

Culture growth parameters, $\mathrm{pH}$ values and algal dry weight were estimated according to Vonshak (1986). Culture concentrations were determined as optical density (OD) by spectrophotometer at $560 \mathrm{~nm}$ Leduy and Therien (1977). Electric conductivity (EC) of algal culture filtrates was measured using glass electrode conductivity meter Model Jenway 4310.

Table (2): Algal culture growth parameter.

\begin{tabular}{|c|c|c|c|c|}
\hline Treatments & EC & $\mathrm{pH}$ & $\begin{array}{l}\text { (OD) at } \\
560 \mathrm{~nm}\end{array}$ & $\begin{array}{c}\text { D.WI } \\
100 \mathrm{ml}\end{array}$ \\
\hline Anabaena azollae & 0.20 & 6.39 & 1.42 & 0.40 \\
\hline Spirulina platensis & 17.76 & 9.48 & 0.97 & 1.76 \\
\hline Azolla pinnata & 1.68 & 7.50 & 4.3 & 0.32 \\
\hline Olive mill & 3.34 & 6.90 & 1.05 & 0.45 \\
\hline Pleurotus columbinus & 1.28 & 6.49 & 1.15 & 0.27 \\
\hline Anabaena azollae + Spirulina platensis. & 8.92 & 9.48 & 0.76 & 0.49 \\
\hline Anabaena azollae +Azolla pinnata & 1.30 & 6.95 & 6.03 & 0.27 \\
\hline Anabaena azollae + olive mill & 1.85 & 6.64 & 1.39 & 0.20 \\
\hline Spirulina platensis +Azolla pinnata & 10.04 & 8.90 & 1.76 & 0.75 \\
\hline Azolla pinnata + olive mill & 2.23 & 6.20 & 4.53 & 0.50 \\
\hline Spirulina platensis + olive mill & 10.91 & 8.42 & 1.02 & 4.09 \\
\hline $\begin{array}{l}\text { Anabaena azollae + Spirulina platensis +Azolla } \\
\text { pinnata + olive mill }\end{array}$ & 6.53 & 7.91 & 0.92 & 0.10 \\
\hline $\begin{array}{l}\text { Anabaena azollae + Spirulina platensis +Azolla } \\
\text { pinnata + olive mill + Pleurotus columbinus }\end{array}$ & 5.40 & 7.17 & 4.03 & 0.53 \\
\hline
\end{tabular}


5. Efficacy of S. platensis, $A$. azollae, $A$. pinnata, olive mill and $P$. columbinus on the activity of $M$. javanica juveniles under laboratory conditions

For studying the efficacy of Spirulina platensis culture filtrates, Azolla pinnata, Anabaena azollae, olive mill and Pleurotus columbinus on $M$. javanica juveniles in vitro, $1 \mathrm{ml}$ of each treatment at three concentrations $(1: 10,1: 25,1: 50)$ of the prepared stock filtrates was added separately to $1 \mathrm{ml}$ of nematode suspension containing 100 juveniles in glass vials. The numbers of active and non-active juveniles were examined and counted microscopically after 24, 48 and 72 hours. New blue R $(0.05 \%$ aqueous solution), potassium permanganate $(0.062-0.50 \% \mathrm{KMnO} 4$ in aqueous solution) and chrysoidin were used to stain dead nematodes Barker et al. (1985).

The treatments were as follows:

1. Spirulina platensis.

3. Olive mill waste water.

5. Pleurotus columbinus.

6. Efficacy of S. platensis, $A$. azollae, $A$. pinnata, olive mill and $P$. columbinus individually and/or in combination on banana infected by $M$. javanica under productivity greenhouse conditions

This experiment was conducted under productivity greenhouse conditions of (Gezerat El Dahab) Giza Governorate, during the summer season of 2013. The soil texture was clay loamy, soil $\mathrm{pH}$ in water suspension (l:2.5) was 7.5 and $\mathrm{EC}$ of soil paste at $25^{\circ} \mathrm{C}$ was $1.3 \mathrm{ds} \cdot \mathrm{m}^{-1}$ AOAC (1980).

Banana plants, cv. Grand Naine', were cultivated in nine productivity greenhouses in soil naturally infested with $M$. javanica. Each productivity greenhouse was divided into 5 ridges ( 40 meters in length and 1 meter in width) at a spacing of $45 \mathrm{~cm}$ between plants within the row. Drip irrigation was used. The treatments were fourteen, each applied to three rows and the last three rows were left without treatment (nematode only) to serve as control. All treatments were applied at the rate of $25 \mathrm{ml} . \mathrm{m}^{-2}$, as soil drench added twice, after 7 and 21 days. Plants were carefully uprooted fruits were weighed after four months. Thereafter, the number of juveniles per $250 \mathrm{~g}$ soil and nematode populations in roots were counted according to Franklin and Goodey (1957).

The treatments were as follows:

1. Spirulina platensis.

3. Azolla pinnata.

5. Olive mill waste water.

7. Anabaena azollae +Azolla pinnata.
2. Anabaena azollae.

4. Pleurotus columbinus.

6. Anabaena azollae + Spirulina platensis. 
8. Anabaena azollae + olive mill waste water.

9. Spirulina platensis +Azolla pinnata. 10. Azolla pinnata + olive mill waste water.

11. Spirulina platensis + olive mill waste water.

12. Anabaena azollae + Spirulina platensis + Azolla pinnata + olive mill waste water.

13. Anabaena azollae + Spirulina platensis +Azolla pinnata + olive mill waste water + Pleurotus columbinus

14. Oxamyl (vydate) as nematicide at the recommended concentration (24\% EC), and

15. Nematodes $(\mathrm{N})$ alone (control).

\section{Statistical analysis procedure}

All obtained data were subjected to analysis of variance (ANOVA) Gomez and Gomez (1984) and means were compared by using L.S.D. at $5 \%$ level of significance.

\section{Results and Discussion}

\section{Efficacy of $S$. platensis, $A$. azollae, $A$. pinnata, olive mill and $P$. columbinus on the activity of $M$. javanica juveniles under laboratory conditions}

Data in Table 3 illustrate that treatment filtrates had various degrees of effectiveness toward the mortality percentages of nematode juveniles. Moreover, the percentage of mortality increased with increasing the concentration and exposure period. Spirulina platensis $(1: 10)$ recorded the highest mortality percentages of nematode juveniles of 79.5, 82.3 and 85.2 after 24,48 and 72 hrs exposure time, respectively. Anabaena azollae, Azolla pinnata and Pleurotus columbinus ranked in the second level in nematode juveniles mortality $\%$ at $1: 10$ during all exposure periods. Treatments showed lethal effect on nematode juveniles and the mortality percentages were over 70 after 72 hours except olive extract which achieved $71.7 \%$. By increasing the exposure period to $72 \mathrm{hrs}$. the mortality percentages raised to $85.2,81.4,79.9,73.5,71.7$ and $70.1 \%$, respectively with Spirulina platensis, Anabaena azollae, Azolla pinnata, Pleurotus columbinus and olive mill. On the other hand, olive extract had the lowest effect on nematode juveniles percentage (71.7) at 1:10 by the end of the exposure period (72 hrs.).

Obtained results indicated that blue green algae, Spirulina platensis produced a great variety of secondary metabolites Gervick et al. (2001), such as nitrogencontaining compounds, polyketides, lipopeptides, cyclic peptides and others. Efficacies of algal culture filtrates decreased with their dilution that may be due to the differences in toxic substances present in the culture filtrates. Similarly, Khan et al. (1997) reported that the efficacy of culture filtrates of the cyanobacterium Microcoleus vaginatus against egg hatching and mortality of Meloidogyne incognita 
was dependent on its concentration and period of exposure.

High mortality percentages recorded for nematode juveniles exposed to the algal culture filtrates may be due to the presence of some phenolic compounds and mineral salts that facilitate and accelerate the rate of penetration of algal byproducts through snail's skin, hence increasing their harmful effects Mahmoud (2001) and Shawky et al. (2009).

Presence of high quantities of acrylic acid in Spirulina was substantiated at the end of the seventies. This substance shows anti-microbial activity, at a $2 \mathrm{mg} / \mathrm{l}$ of biomass concentration. Propionic, benzoic and mandelic organic acids were also found Lee (2004). Abd El-Baky et al. (2009) indicated that S. platensis secretes organic substances or metabolic products such as phycobiline, phenols, terpenoids, steroids, polysaccharides and saponins. Low concentrations of saponin fractions increased mortality of $B$. alexandrina snails, miracidia, cercariae and adult worms of Schistosoma mansoni, and decrease the egg production Tadros et al (2008).

Table (3): Effect of S. platensis, A. azollae, A. pinnata, $P$. columbines and olive mill on the activity of $M$. javanica juveniles under laboratory conditions.

\begin{tabular}{|c|c|c|c|c|}
\hline \multirow{3}{*}{ Treatments } & \multirow{3}{*}{ Conc. } & \multicolumn{3}{|c|}{ Exposure periods (in hours) } \\
\hline & & 24 & 48 & 72 \\
\hline & & \multicolumn{3}{|c|}{ Mortality \% } \\
\hline \multirow{3}{*}{ Spirulina platensis } & $1: 50$ & 71.4 & 75.6 & 79.1 \\
\hline & $1: 25$ & 76.1 & 78.4 & 83.7 \\
\hline & 1:10 & 79.5 & 82.3 & 85.2 \\
\hline \multirow{3}{*}{ Azolla pinnata } & $1: 50$ & 61.2 & 65.8 & 68.3 \\
\hline & $1: 25$ & 69.4 & 71.9 & 74.5 \\
\hline & $1: 10$ & 74.3 & 76.7 & 79.9 \\
\hline \multirow{3}{*}{ Anabaena azollae } & $1: 50$ & 67.9 & 69.7 & 71.5 \\
\hline & $1: 25$ & 73.5 & 75.1 & 77.9 \\
\hline & $1: 10$ & 78.9 & 79.2 & 81.4 \\
\hline \multirow{3}{*}{ Pleurotus columbinus } & $1: 50$ & 56.6 & 59.4 & 63.1 \\
\hline & $1: 25$ & 65.8 & 68.5 & 71.4 \\
\hline & $1: 10$ & 69.1 & 71.7 & 73.5 \\
\hline \multirow{3}{*}{ Olive mill } & $1: 50$ & 54.8 & 57.1 & 61.7 \\
\hline & $1: 25$ & 63.7 & 67.8 & 69.5 \\
\hline & $1: 10$ & 67.9 & 69.4 & 71.7 \\
\hline Oxamyl & & 81.7 & 85.4 & 89.6 \\
\hline Nematode alone & & 0.7 & 1.1 & 1.9 \\
\hline
\end{tabular}




\section{Efficacy of $S$. platensis, $A$. azollae, $A$. pinnata, $P$. columbines and olive mill} on banana infection by $M$. javanica under productivity greenhouse conditions

Data in Table 4 reveal that the combination of $S$. platensis, $A$. azollae, $A$. pinnata, $P$. columbines and olive mill resulted in the lowest final population of $M$. javanica (PF) compared with the other treatments, whereas the highest final population of $M$. javanica was associated with the individual treatment of olive mill only after two, three months of application. The combination of $S$. platensis, $A$. azollae, $A$. pinnata, $P$. columbines and olive mill induced resistance in banana roots against $M$. javanica. Results were achieved by Khan et al. (2005), who suggested that the application of algal filtrate helped the plant to resist nematode attack or may played a direct role in the plant defense mechanism. Microorganisms and compounds of microbial origin have been found to induce defense responses and/or resistance in plants towards pathogens. Also, Shawky et al. (2009) reported that in the productivity greenhouse experiment, the combination of five algal culture filtrates of $S$. platensis, Oscillatoria sp., A. oryzae, N. muscorum and $P$. fragile with $A$. pinnata and compost extract achieved the highest reduction in the number of the $2^{\text {nd }}$ stage juveniles in soil, the numbers of galls, developmental stages, females, egg masses, egg numbers/egg mass in roots of cucumber plants comparing with the individual treatment and the non treated control

The efficacy of $S$. platensis, $A$. azollae, A. pinnata, $P$. columbines and olive mill in comparison with oxamyl were tested under productivity greenhouse conditions in an experiment lasted four months. Data in Table 4 showed that all tested treatments were effective in decreasing the final nematode population and rate of build-up of root knot nematode in both soil and roots. Total nematode population in both soil and root samples revealed the suppressive effect of all materials on the nematode counts. In general, the nematode counts decreased gradually in both soil and root of treated plants. All treatments decreased in the total nematode population ranging between 320 and 1680 one month after treatment in comparison to the control that reached 2400 . Then, remarkable suppression in nematode counts obtained after three months in both soil and root samples. The combination of $S$. platensis, A. azollae, A. pinnata, $P$. columbines and olive mill resulted in the highest decrease in the total number of nematodes in both soil and root samples as soil application and the highest efficacy treatments reached to $86 \%$ after the three months in comparison with the other treatments after the oxamyl treatment that reached $89 \%$ while, olive mill was the lowest efficacy treatment that reached $63 \%$ after the three months. These results agree with Shawky et al. (2009), Shawky et al. (2010) and Soliman et al. (2011). 
Table (4): Efficsoy of S. platensis, A. azollae, A. pirnata, P. colum bines and olive mill in combination $\alpha$ single application on banana infection by M. javanica under productivity greenhouse condibions.

\begin{tabular}{|c|c|c|c|c|c|c|c|c|c|}
\hline \multirow[b]{2}{*}{ Treatnents } & \multirow{2}{*}{ 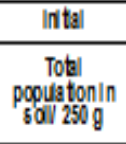 } & \multirow{2}{*}{$\begin{array}{c}\text { After one month } \\
\text { Total population } \\
\text { In } 801 / 250 \mathrm{gag} \\
+ \text { in rootg }\end{array}$} & \multirow{2}{*}{$\mathrm{PFIPI}$} & \multicolumn{2}{|c|}{ After two months } & \multicolumn{2}{|c|}{ After three months } & \multicolumn{2}{|l|}{ After four months } \\
\hline & & & & $\begin{array}{c}\text { Toa } \\
\text { populationin } \\
\text { solll } 2509 \\
+ \text { in rootly }\end{array}$ & PFIR & $\begin{array}{l}\text { Tog } \\
\text { population in } \\
\text { sol/250g + in } \\
\text { roofg }\end{array}$ & PFIPI & 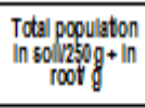 & PFPI \\
\hline A. 320132 & 1820 & $\begin{array}{l}1560 \\
+(33)\end{array}$ & 0.85 & $\begin{array}{l}1440 \\
+(54)\end{array}$ & 0.79 & $\begin{array}{l}1300 \\
+(66)\end{array}$ & 0.71 & $\begin{array}{l}1420 \\
(65)\end{array}$ & 0.78 \\
\hline S. platensis & 1940 & $\begin{array}{l}1600 \\
+(35)\end{array}$ & 0.82 & $\begin{array}{l}1470 \\
+(56)\end{array}$ & 0.75 & $\begin{array}{l}1320 \\
+(67)\end{array}$ & 0.68 & $\begin{array}{l}1500 \\
-(66)\end{array}$ & 0.77 \\
\hline A pinnata & 1860 & $\begin{array}{l}1640 \\
-(31)\end{array}$ & 0.88 & $\begin{array}{l}1480 \\
+(53)\end{array}$ & 0.79 & $\begin{array}{l}1320 \\
+(66)\end{array}$ & 0.70 & $\begin{array}{l}1490 \\
+(64)\end{array}$ & 0.80 \\
\hline Olie mil & 1820 & $\begin{array}{l}1680 \\
+277)\end{array}$ & 0.92 & $\begin{array}{r}1540 \\
+(50)\end{array}$ & 0.84 & $\begin{array}{l}1400 \\
+(63)\end{array}$ & 0.76 & $\begin{array}{l}1560 \\
+(62)\end{array}$ & 0.85 \\
\hline P. cumbinus & 1800 & $\begin{array}{l}1600 \\
+(30)\end{array}$ & 0.88 & $\begin{array}{l}1480 \\
+(52)\end{array}$ & 0.82 & $\begin{array}{l}1360 \\
+(64)\end{array}$ & 0.75 & $\begin{array}{l}1500 \\
+(63)\end{array}$ & 0.83 \\
\hline A. andae +S platensis. & 1820 & $\begin{array}{l}960 \\
469)\end{array}$ & 0.52 & $\begin{array}{l}820 \\
+74)\end{array}$ & 0.45 & $\begin{array}{l}740 \\
+(81)\end{array}$ & 0.40 & $\begin{aligned} 840 \\
+80)\end{aligned}$ & 0.43 \\
\hline A. 320 last A. plnnata & 1800 & $\begin{array}{l}1320 \\
-(42)\end{array}$ & 0.73 & $\begin{array}{l}1260 \\
+(59)\end{array}$ & 0.70 & $\begin{array}{l}1180 \\
+(69)\end{array}$ & 0.65 & $\begin{array}{l}1280 \\
+(68)\end{array}$ & 0.67 \\
\hline A. andse tolve mll & 1940 & $\begin{array}{l}1460 \\
-(41)\end{array}$ & 0.75 & $\begin{array}{l}1400 \\
+(58)\end{array}$ & 0.72 & $\begin{array}{l}1300 \\
+(68)\end{array}$ & 0.67 & $\begin{array}{l}1420 \\
+(67)\end{array}$ & 0.73 \\
\hline$S$ p platensis $+A$ pinnata & 1800 & $\begin{array}{l}1240 \\
+(18)\end{array}$ & 0.65 & $\begin{array}{l}1180 \\
+(63)\end{array}$ & 0.62 & $\begin{array}{l}960 \\
+(76)\end{array}$ & 0.51 & $\begin{array}{l}1040 \\
-75)\end{array}$ & 0.55 \\
\hline A. plinnata + olve mll & 1960 & $\begin{array}{l}1500 \\
+(40)\end{array}$ & 0.76 & $\begin{array}{l}1440 \\
(57)\end{array}$ & 0.73 & $\begin{array}{l}1360 \\
+(67)\end{array}$ & 0.69 & $\begin{array}{l}1480 \\
+(66)\end{array}$ & 0.70 \\
\hline S platensis + olve mll & 1900 & $\begin{array}{l}1280 \\
4(47)\end{array}$ & 0.67 & $\begin{aligned} & 1150 \\
+(65) & \end{aligned}$ & 0.60 & $\begin{array}{r}980 \\
475\end{array}$ & 0.51 & $\begin{array}{l}1180 \\
+72)\end{array}$ & 0.57 \\
\hline $\begin{array}{l}\text { A.azlas + S platensis th. plinnata +olve } \\
\text { mll }\end{array}$ & 1920 & $\begin{array}{l}640 \\
-(74)\end{array}$ & 0.33 & $\begin{array}{r}720 \\
+78)\end{array}$ & 0.37 & $\begin{array}{r}800 \\
+(80)\end{array}$ & 0.41 & $\begin{array}{l}920 \\
\cdot(79)\end{array}$ & 0.47 \\
\hline 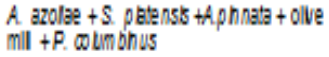 & 1940 & $\begin{array}{l}570 \\
.77)\end{array}$ & 0.29 & $\begin{aligned} 500 \\
+(86)\end{aligned}$ & 0.25 & $\begin{array}{l}560 \\
566)\end{array}$ & 0.28 & $\begin{array}{l}720 \\
+(84)\end{array}$ & 0.37 \\
\hline Qamyl & 1900 & $\begin{array}{l}500 \\
+\infty 00\end{array}$ & 0.26 & $\begin{array}{r}460 \\
+867\end{array}$ & 0.24 & $\begin{array}{r}40 \\
+89\end{array}$ & 0.23 & $\begin{array}{r}560 \\
+877\end{array}$ & 0.29 \\
\hline $\begin{array}{l}\text { Nematodes alone } \\
\text { L.S. D. at } 0.05 \%\end{array}$ & $\begin{array}{l}1900 \\
19.1\end{array}$ & $\begin{array}{l}2400 \\
16,7\end{array}$ & $\begin{array}{l}1.26 \\
0.11\end{array}$ & $\begin{array}{l}3200 \\
10.9\end{array}$ & $\begin{array}{l}1.68 \\
024\end{array}$ & $\begin{array}{l}3900 \\
146\end{array}$ & $\begin{array}{l}205 \\
0.20\end{array}$ & $\begin{array}{l}4200 \\
112\end{array}$ & $\begin{array}{l}221 \\
0.17\end{array}$ \\
\hline
\end{tabular}


Treatments of $S$. platensis, $A$. azollae, $A$. pinnata aqueous extract filtrate, $P$. columbines and olive mill waste water in single and/or in combined applications caused remarkable decreases in the number of root galls under greenhouse conditions. Fig. 1 shows that the combination treatment of S. platensis, A. azollae, A. pinnata aqueous extract filtrate, $P$. columbines and olive mill waste water resulted in the lowest number of root galls, whereas, the individual treatment of olive extract showed the highest number of root galls compared to the other treatments. The same trend was obtained with number of developmental stages, females, egg masses and eggs numbers/root.

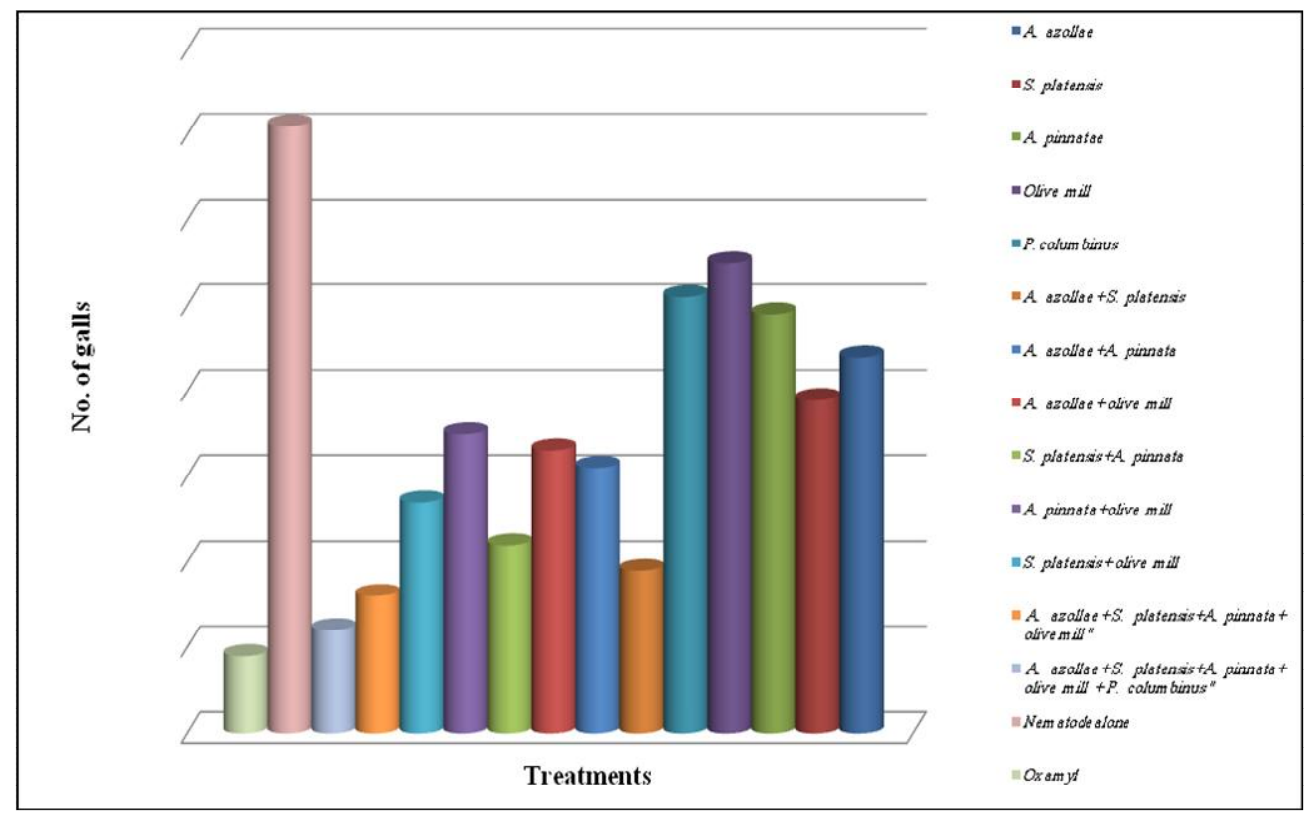

Fig. (1): Effect of $S$. platensis, A. azollae, A. pinnata, P. columbines and olive mill in combination or single application on the number of galls of $M$. javanica on banana plants under productivity greenhouse conditions.

Yield of banana plants infected with $M$. javanica in the productivity greenhouse is shown in Fig. 2. The yield was the highest with the combination of S. platensis, A. azollae, A. pinnata aqueous extract filtrate, $P$. columbines and olive mill waste water $47 \%$ over control, while, the individual treatment of olive mill waste water recorded the lowest percentage increase 10. Liu et al. (2008) found that the stimulation of plant growth by using compost + compost tea or seaweed extracts may be attributed to the combined effect of compost, compost tea (which contains humic acids, vitamins, amino acids and both macro and micro nutrients which enhanced cucumber growth) and seaweed extracts which contain some growth regulators such as cytokinins, auxin and gibberellins. 


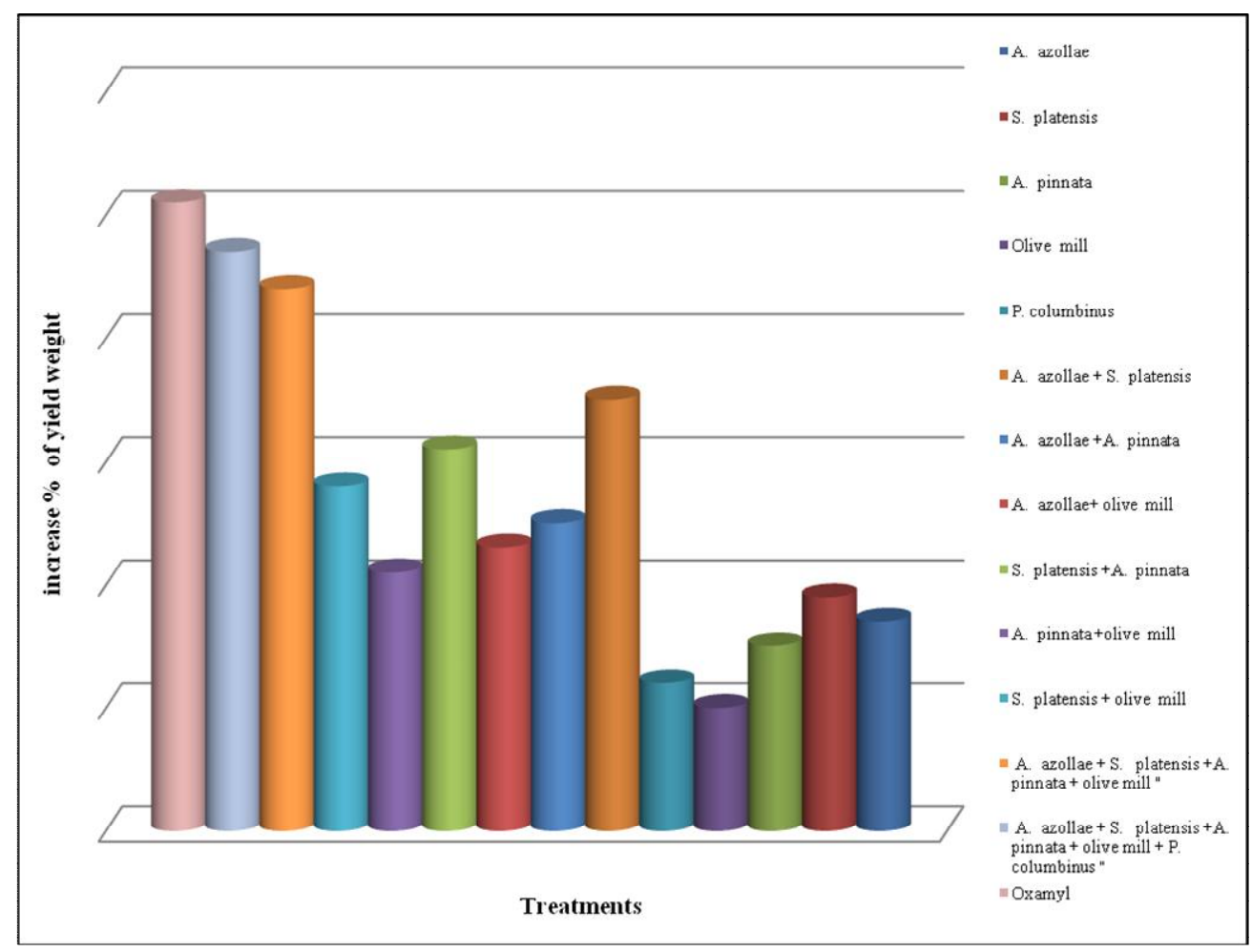

Fig. (2): Effect of S. platensis, A. azollae, A. pinnata, P. columbines and olive mill in combination or single application on increase \% of yield weight of banana plants infected with $M$. javanica under productivity greenhouse conditions.

Shawky et al. (2009) mentioned that, in the productivity greenhouse experiment, the combination of five algal culture filtrates of $S$. platensis, Oscillatoria sp., $A$. oryzae, N. muscorum and $P$. fragile with $A$. pinnata aqueous extract filtrate and compost extract achieved the highest reduction in the number of nematodes and in roots of cucumber plants comparing with the individual treatment and the non treated control. In addition, all combinations significantly improved fresh weight of roots and shoots and increased the yield of cucumber plants.

\section{Biological and chemical analyses of $M$. javanica infected soil remaining after banana harvesting}

The remaining soil after banana harvesting was analyzed to record the changes in soil biological and chemical conditions due to the different treatments in the productivity greenhouse experiment. Generally, all the combined treatments enhanced soil biological activity than the individual ones Table 5. 
Table (5): Biological activity of $M$. javanica infected soil remaining after banana harvesting.

\begin{tabular}{|c|c|c|c|}
\hline Treatments & $\begin{array}{l}\mathrm{CO}_{2} \text { evolution } \\
\left(\mathrm{mg}^{100 \mathrm{~g} \text { soil }^{-1}}\right)\end{array}$ & $\begin{array}{c}\text { Dehydrogenase } \\
\text { activity ( } \mu \mathrm{g} \\
\text { TPFg }^{-1} \text { dry soil }^{-1} \\
\text { Day }^{-1} \text { ) }\end{array}$ & $\begin{array}{c}\text { Nitrogenase } \\
\text { activity } \\
\left(\mu \text { mole } \mathrm{C}_{2} \mathrm{H}_{4}\right. \\
\text { g soil }^{-1} \mathrm{hr}^{-1} \text { ) }\end{array}$ \\
\hline A. azollae & 44 & 24.23 & 226.67 \\
\hline S. platensis & 50.6 & 25.46 & 73 \\
\hline A. pinnata & 45 & 24.51 & 182.59 \\
\hline Olive mill & 30.8 & 21.9 & 55 \\
\hline P. columbinus & 33 & 23.82 & 62 \\
\hline A.azollae + S. platensis & 110.0 & 28.07 & 583.47 \\
\hline A. azollae $+A$. pinnata & 66 & 27.39 & 489.97 \\
\hline A. azollae + olive mill & 51.7 & 26.43 & 245.64 \\
\hline S. platensis + A. pinnata & 220.0 & 28.76 & 644.69 \\
\hline A. pinnata +olive mill & 61 & 26.56 & 430.02 \\
\hline S. platensis + olive mill & 67 & 27.39 & 562.29 \\
\hline $\begin{array}{l}\text { A. azollae }+S \text {. platensis }+A \text {. pinnata } \\
+ \text { olive mil }\end{array}$ & 146.3 & 39.99 & 872.41 \\
\hline $\begin{array}{l}\text { A. azollae }+S \text {. platensis }+A \text {. pinnata } \\
+ \text { olive mill }+P \text {. columbinus }\end{array}$ & 220 & 44.24 & 1015.09 \\
\hline Oxamyl & 270.0 & 46.16 & 3012.57 \\
\hline Nematode only & 16.5 & 14.23 & 42.11 \\
\hline L. S. D. at $0.05 \%$ & 5.4 & 3.7 & 78.5 \\
\hline
\end{tabular}

The superiority of biological activity of the soil was due to the synthetic nematicide; (oxamyl). The combined treatment of $A$. azollae $+S$. platensis $+A$. pinnata $+P$. columbinus + olive mill revealed the highest soil biological activity compared with other treatments. All treatments affected significantly the biological activity of the soil, Table 5.

It could be noticed that dehydrogenase and nitrogenase activities, as well as CO2 production, in all treatments were higher compared to control. The maximum microbial activity was achieved by the chemical pesticide followed by combined effect of biofertilizer with olive mille as soil organic amendment. While, the changes of biological activity in root rhizosphere were greatly fluctuated among the other treatments, Moreover, the application of both Azolla and cyanobacteria enhanced the soil microbial activity. Obtained results are in line with those found by Waseem et al. (2012) who reported biological health of the soil due to application of Azolla has resulted in improving mineralization and consequent increase microbial status of the soil. Also, cyanobacteria promoted establishment of microbial population, increased organic matter and nutrient content and soil stability Acea et al. (2003). The blue green algae positively affected plant characteristics which led to improve 
in yield and fruit quality of banana trees. These results are in agreement with those obtained by Mahmoud et al. (2007), who reported that cyanobacteria combined, with organic amendments significantly enhanced the soil biological activity represented by dehydrogenase, nitrogenase and phosphatase activities. Also, Shawky et al.(2009) said that in the productivity greenhouse experiment, the combined treatment of mixed algal culture filtrates $+A$. pinnata aqueous extract filtrate + compost extract significantly enhanced the soil biological activity in terms of total bacterial count, total cyanobacterial count, $\mathrm{CO}_{2}$ evolution, dehydrogenase and nitrogenase activities.

It could be recommended that application of bio-control agents of mixed $A$. azollae $+S$. platensis $+A$. pinnata + olive mill waste water $+P$. columbinus as plant growth promoting substances to increase plant nutrients availability and has nematicidal effect to control root knot nematode in banana.

\section{References}

Abad P., Favery B., Rosso M. and Castagnone-Sereno P. (2003). Root-knot nematode parasitism and host response: molecular basis of a sophisticated interaction. Mol. PI. Path., 4: 217-224.

Abd El-All Azza (2013). Characterization of Anabaena azollae isolated from Azolla Pinnat. Egypt.J.Agric.Res., 91 (3): 801-807.

Abd El-Baky H.H., El Baz F.K. and El-Baroty G.S. (2009). Phenolics from Spirulina maxima: Over-production and in vitro protective effect of its phenolics on $\mathrm{CCl} 4$ induced hepatotoxicity. Journal of Medicinal Plants Research, 3(1): 24-30.

Acea, M.J.; Prieto.F, A.; and Diz,C. N. (2003). "Cyanobacterial inoculation of heated soils: effect on microorganisms of $\mathrm{C}$ and $\mathrm{N}$ cycles and chemical transformation. Plant and Soil, 34:17- 28.

Anastasiadis I.A., Giannakou I.O., Prophetou-Athanasiadou D.A. and Gowen S.R. (2008). The combined effect of the application of a biocontrol agent Paecilomyces lilacinus, with various practices for the control of root-knot nematodes. Crop Prot., 27: 352-361.

AOAC (1980). Official Methods of Analysis of the Association of Official Analytical Chemist. $12^{\text {th }}$ ed. Washington, D.C., USA.

Barker, K.R.; Carter, C.C. and Sasser, J.N. (1985). An advanced treatise on Meloidogyne vol.2 Methodology pag. 41

Casida L. E., Klein D.A. and Santoro T. (1964). Soil dehydrogenase activity. Soil Sci., 98: 371-376. 
Dart P.J., Day J.M. and Harris D. (1972). Assay of nitrogenase activity by acetylene reduction. In: Use of isotopes for study of fertilizer utilization by legume crops. FAO/IAEA Technical Report Series, 149: 85-97.

Fay P. (1983). The Blue-Greens. Edward Arnold, London.

Franklin M.T. and Goodey J.B. (1957). A cotton-blue lactophenol technique for mounting plant parasitic nemato des. J. Helminthological Abstracts, 23: 175- 178.

Gaur A.C., Sadasivan K.V., Vimal O.P. and Mathur R.S. (1971). A study of decomposition of organic matter in an alluvial soil. $\mathrm{CO}_{2}$ evolution, microbiological and chemical transformation. Plant and Soil, 34:17-28.

Gervick W.H., Tan L.T. and Siachitta N. ( 2001). In: Cordell, G. (Ed.), The Alkaloids, Vol. 57. Academic Press, San Diego, p. 75-184.

Gomez K. W. and Gomez A. A. (1984). Statistical procedures for agricultural research $2 \frac{\text { nd }}{}$ Ed. p. 680 John Wiley and Sons inc, New York.

Henderson, G.E. and E.W. Tillton. (1955). Test with acaricides against the brown wheat mite. J. Econ. Entomol.,48:157-161.

Khan Z., Jairajpuri M.S. and Khan M.W. (1997). Effect of culture filtrate of a bluegreen alga Microcoleus vaginatus on mortality and hatching of root-knot nematode Meloidogyne incognita. International Journal of Nematology, 7: 100-102.

Khan Z., Park S.D., Shin S.Y., Bae S.G., Yeon I.K. and Seo Y.J. (2005). Management of Meloidogyne incognita on tomato by root-dip treatment in culture filtrate of the blue-green alga Microcoleus vaginatus. Bioresource Technology, 96: 1338-1341.

Leduy, A. and N. Therien (1977). An improved method for optical density measurement of semimicro blue-green alga Spirulina maxima. Biotechnol Bioeng. 19:1219-1222

Lee Y. (2004). Microalgal mass culture system and methods: their limitation and potential. J. Appl. Phycology,13(4): 1573-1576.

Liu T., Wang L., Duan Y.X. and Wang X. (2008). Nematicidal activity of culture filtrate of Beauveria bassiana against Meloidogyne hapla. World J. Microbiol. Biotechnol., 24: 113-118.

Mahmoud A.A., Mostafa, S.S.M., Abd El-All,A. A.M. and Hegazi A.Z. (2007). Effect of cyanobacterial inoculation in presence of organic and inorganic amendments on carrot yield and sandy soil properties under drip irrigation regime. Egypt. J. of Appl. Sci., 22(12B):716-733. 
Mahmoud M. B. (2001). Physiological Studies on Biomphalaria alexandrina Snails and Their Susceptibility to Schistosoma mansoni Infection. Ph.D. Thesis, Fac. Science, Ain Shams Univ., Cairo, Egypt 118 pp.

Martin, J.D. (1950). Use of acid rose Bengal and Streptomycien in the plate method for estimating soil fungi.Soil Sci., 69: 215.

Meadows J., Gill S.S. and Bone L.W. (1989). Factors influencing lethality of Bacillus thuringiensis kurstaki toxin for eggs and larvae of Trichostrongylus colubriformus (Nematoda). Journal of Parasitology, 75:191-194.

Oka Y., Koltai H., Bar-Eyal M., Mor M., Sharon E., Chet I. and Spiegel Y. (2000). New strategies for the control of plant parasitic nematodes. Pest Manage. Sci., 56:983-988.

Oostendrop M. and Sikora R. A. (1989). Seed treatment with antagonistic rhizobacteria for the suppression of Heterodera schachtii early root infection of sugar-beet. Revue Nematologie, 12:77-83.

Rippka, R., J. Deruelles, J. B. Waterburg, M. Herdman and R.Y. Stanier (1979). Generic assignments,strain histories and properties of pure cultures of cyanobacteira. J. of General Microbiol, 111: 1-16.

Shawky, Samaa M., A.E. Khalil and Manal M. Soliman (2010). Non chemical control of root-knot nematode; Meloidogyne javanica on peanut in Egypt. Zagazig J. Agric. Res., 37 (1): 185-206.

Shawky, Samaa M. ; Soha S. M. Mostafa and Azza A. M. (2009). Efficacy of some algal, Azolla and compost extract in controlling root-knot nematode and its reflection on cucumber. Bull. Fac. Agric., Cairo Univ. 60:443-459

Soliman Amira Sh., Shawky Samaa M. and Omar M. N. A. (2011). Efficency of bioagents in controlling root knot-nematode on Acacia plants in Egypt. American-Eurasian J. Agric. \& Environ. Sci., 10(2):223-229.

Tadros M.M., Ghaly N.S. and Moharib M.N. (2008). Molluscicidal and schistosomicidal activities of a steroidal saponins-containing fraction from Dracaena fragrans (L.). J. Egypt. Soc. Parasitol., 38 (2): 585-598.

Tahmid, H. Ansari, M. A. Malek, M.U. Ahmed, Sota Tanak and Tetsushi Yoshida (2002). Influence of Azolla pinnata in combination with mustard oil cake on galling of Meloidogyne javanica and growth of eggplant. Pakistan Journal of Biological Sciences 5(6): 665-668.

Waseem, R.; Preeti, R.; Suchit, A. J., and Pramod, W. R. (2012). AzollaAnabaena Association and Its Significance in Supportable Agriculture. J. Biol. \& Chem., 40 (1): 1-6. 
Westcott III S.W. and Kluepfel D.A. (1993). Inhibition of Criconemella xenoplax egg hatch by Pseudomonas aureofaciens. Phytopathology, 83: 1245-1249.

Vonshak A. (1986). Laboratory techniques for the cultivation of microalgae. In Handbook of microalgal mass culture. (ed. A. Richmond). Boca Raton:CRC Press.

Yoshida, S.; Forno, D. A.; Cock, J. H. and Gomez, K. A.(1976). Laboratory manual for physiological studies for rice. I.R.R.I., The Philippines.

Zaccaro M.C., Salazar C., Zulpa de G., Caire Stroni de M.M., Cans and Stella A.M. (2001). Lead toxicity in cyanobacterial prophyrin metabolism. Environ. Toxocol.and water Quality, 16: 61-67.

Zarrouk C. (1966). Contribution á l'étude d'une cyanophycée. Influence de divers facteurs physiques et chimiques sur la croissance et la photosynthése de Spirulina maxima (Setch. Et Gardner) Geitler. Ph. D. Thesis, University of Paris, France 87 pp. 


\section{الملخص العربي}

مقارنة كفاءة استخدام بعض أنواع الطحالب والازولا وعيش الغراب ومخلفات الزيتون في مكافحة نيماتودا تعقد الجذور على الموز

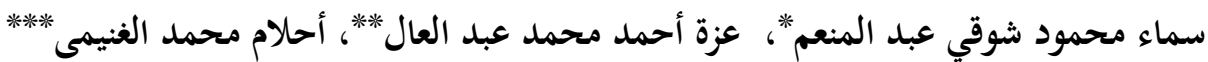

$$
\begin{aligned}
& \text { * قسم بحوث الأمراض النيماتودية - معهد بحوث أمراض النباتات- مركز البحوث الزراعية - الجيزة- مصر. }
\end{aligned}
$$

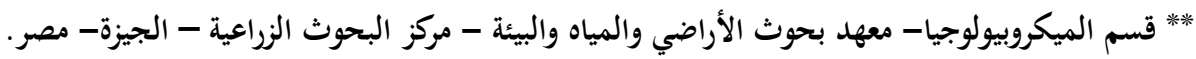

$$
\begin{aligned}
& \text { |**** قسم وقاية النبات - وحدة النيماتودا - مركز بحوث الصحراء - القاهرة - مصر. }
\end{aligned}
$$

تهدف هذه الدراسة إلى استخدام اثنين من المزارع الطحلبية وهي: Spirulina platensis, Anabaena azollae وفطر عيش الغراب والمستخلص المائي لمخلفات عصر الزيتون لمقاومة نيماتودا تعقد الجذور ظروف المعمل والصوبة الإنتاجية. أظهرت التجارب المعملية موت يرقات النيماتودا بنسبة عالية في كل المعاملات وعند

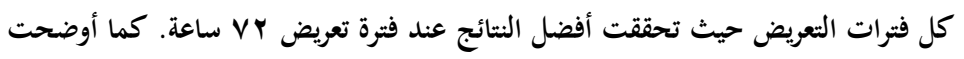

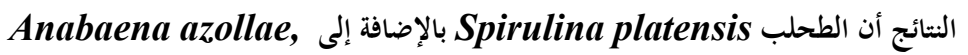
Azolla pinnata, Pleurotus columbinus

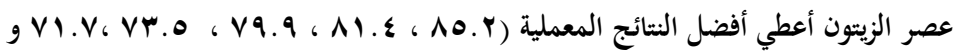

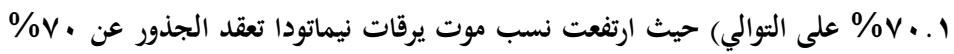

$$
\text { عند التركيز الأعلى (1:1.1 (1). }
$$

أوضحت تجارب الصوبة الإنتاجية أن المعاملة المختلطة من مخلوط راشح مزارع

Spirulina platensis, Anabaena azollae Azolla pinnata, Pleurotus columbinus

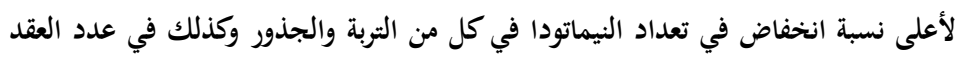

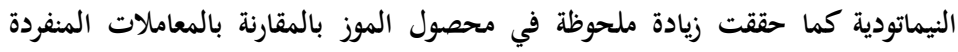

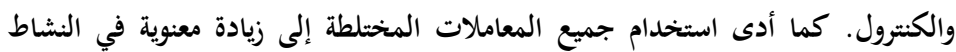

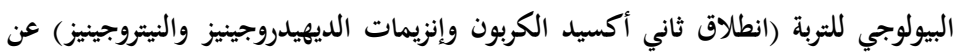

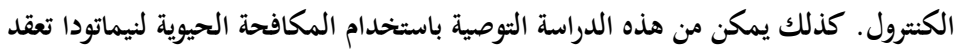
الجذور على الموز لتفادي الآثار السيئة المترتبة عن استخدام المبيدات النيماتودية. 